Hope College

Hope College Digital Commons

Faculty Publications

$1-1-2006$

\title{
Misperceptions in Intergroup Conflict: Disagreeing About What We Disagree About
}

John R. Chambers

University of Florida

Robert S. Baron

University of lowa

Mary L. Inman

Hope College, inman@hope.edu

Follow this and additional works at: https://digitalcommons.hope.edu/faculty_publications

Part of the Psychology Commons

\section{Recommended Citation}

Repository citation: Chambers, John R.; Baron, Robert S.; and Inman, Mary L., "Misperceptions in Intergroup Conflict: Disagreeing About What We Disagree About" (2006). Faculty Publications. Paper 1520.

https://digitalcommons.hope.edu/faculty_publications/1520

Published in: Psychological Science, Volume 17, Issue 1, January 1, 2006, pages 38-45. Copyright @ 2006 SAGE.

This Article is brought to you for free and open access by Hope College Digital Commons. It has been accepted for inclusion in Faculty Publications by an authorized administrator of Hope College Digital Commons. For more information, please contact digitalcommons@hope.edu. 
Running head: INTERGROUP MISPERCEPTION

Accepted Psychological Science, February 2005

Misperceptions in Intergroup Conflict: Disagreeing About What We Disagree About

John R. Chambers and Robert S. Baron

University of Iowa

Mary L. Inman

Hope College

Address correspondence to:

John R. Chambers

E420C Seashore Hall

Department of Psychology

University of Iowa

Iowa City, IA 52242

Office: (319) 335-2397

john-chambers@uiowa.edu 


\begin{abstract}
Two studies examined misperceptions of disagreement in partisan social conflicts, namely in the debates over abortion (Study 1) and national politics (Study 2). We observed that partisans tend to exaggerate differences of opinion with their adversaries. Further, we found that perceptions of disagreement were most pronounced concerning values that were most important or central to the perceiver's own ideology, whereas partisans perceived much less disagreement with respect to values central to their adversaries' ideology. To the extent that partisans assumed disagreement concerning personally-important values, they were also inaccurate in perceiving their adversaries' actual opinions. Discussion focuses on the cognitive mechanisms underlying misperceptions of disagreement and strategies for reducing intergroup conflict suggested by our data.
\end{abstract}




\section{Misperceptions in Intergroup Conflict: Disagreeing About What We Disagree About}

"In all matters of opinion, our adversaries are completely insane"- Oscar Wilde

Members of partisan social groups often view their adversaries with suspicion, distrust, and outright animosity. It is not unusual to hear loyal members of the Republican party complain about Democrat's "attack on traditional family values and the free market" while at the same time hearing loyal Democrats chastise Republicans for their "war on the poor" or their "siege on the environment." Such inflamed beliefs characterize not only disputes between these two political parties, but can also be heard in the debates between other social groups with competing ideologies, such as labor-management conflicts, environmentalist-business struggles, tensions between warring nations, and race-related problems. Undoubtedly, these hostile perceptions fuel much of the conflict and discord that surrounds intergroup relations. This paper explores several open questions about intergroup perception. Just how accurate are partisans at perceiving the motives, goals, and opinions of their adversaries? Where do their perceptions go astray? And why do they do so?

The little work that has been carried out on perception of intergroup attitudes has demonstrated the gross inaccuracies of perceiver's intuitions. In one of the first studies in this area, Robinson and colleagues (Robinson, Keltner, Ward, \& Ross, 1995) presented pro-choice and pro-life college students with scenarios describing cases of abortion (e.g., a high-school age girl who became pregnant). For each scenario, participants expressed the level of sympathy they personally felt regarding the scenario and estimated the level of sympathy felt by the typical prochoice and pro-life participant in the study. Not only did they find widespread perceptions of disagreement among both partisan groups, but these perceptions, when compared to the selfreport ratings made by their adversaries, proved to be greatly exaggerated. For example, pro- 
choice participants assumed they felt more sympathy than the pro-life participants would when, in fact, both groups reported feeling equally sympathetic.

They replicated these perceptions of disagreement with other item responses (e.g., estimates of the number of pregnancies resulting from casual affairs) and with other partisan social groups, pointing to the generality of this finding (see also Keltner \& Robinson, 1996, 1997; Robinson \& Friedman, 1995; Robinson \& Keltner, 1996; Thompson, 1995; Thompson \& Nadler, 2000). These results compliment and extend now classic research inspired by social judgment theory which found that members of partisan groups exaggerated the extremity of messages advocating their adversaries' point of view (e.g., Hovland, Harvey, \& Sherif, 1957).

Our research takes the Robinson et al. (1995) findings as a starting point and extends this research by considering both the exact nature and source of disagreement perceptions. Like Robinson and colleagues, we assume that partisans often exaggerate the extent of disagreement with an outgroup. We differ from them by contending that perceptions of disagreement are most prevalent for those values which are core to, or defining of, the perceiver's own ideological stance. In essence, partisans assume that their adversaries contest the very values they care most deeply about (see the General Discussion a description of the presumed cognitive mechanisms). Thus, we assume that Republicans see Democrats as desiring to undermine traditional family values - one of the values central to the conservative world view-- while Democrats view Republicans as wanting to deprive the rights and opportunities of the poor-one of the values central to the liberal world view. These perceptions may prove faulty because the typical Democrat probably favors family values and the typical Republican probably favors the rights of the poor, and thus, each side will overestimate the true margin of disagreement. 
At the same time, we suspect that partisans will perceive far less disagreement between themselves and the outgroup with respect to values which are core to their adversaries' ideological position. A person with strong pro-choice leanings, for instance, may favor "the value of human life" (a value typically associated with the pro-life stance) and accurately recognize that those on the pro-life side would as well. Hence, the pro-choice person will see minimal difference between her position on this value and that of her pro-life adversaries. In this case, there will be a closer correspondence between what partisans assume their adversaries believe and what their adversaries actually report believing.

We conducted two studies to test our hypotheses about assumed (and factual) bases of disagreement, in the context of the debates over abortion (Study 1) and politics (Study 2). In each study, we asked members of partisan social groups to make judgments regarding value issues that were either central or non-central to their partisan philosophy. In these studies, we selected value issues that were central to the position of a given partisan group while not being central to the position of individuals in the opposing partisan group. For each issue, partisans reported their personal position ("favor" or "oppose") and estimated the position of the typical outgroup member. ${ }^{1}$ As in Robinson et al. (1995), we compared these responses to obtain three types of indexes: actual disagreement (i.e., self-rating vs. outgroup's self-rating), perceived disagreement (i.e., self-rating vs. outgroup estimate) and overestimated disagreement (i.e., outgroup estimate vs. outgroup's self-rating). We predicted that partisans would perceive (and indeed, exaggerate) disagreement with members of the adversarial group most dramatically on those value issues central to their own philosophical position. For less central value issues, we predicted partisans would perceive less disagreement and these perceptions would achieve a greater degree of accuracy. 
Study 1: Abortion

We had college-age students on both sides of the abortion debate express their own positions and estimate the typical outgroup member's position regarding four value issues: the value of human life, a moral code of sexual conduct, women's reproductive freedom, and freedom from government interference in private lives. The former two are issues frequently cited by pro-life persons as a rationale for eliminating legalized abortion. In contrast, pro-choice individuals often mention the latter two issues as grounds to maintain the legal status of abortion. Thus, it appears that these sets of values are central to the pro-life and pro-choice ideological positions, respectively, and therefore examining perceptions regarding these issues afforded a test of our key hypotheses.

\section{Method}

Participants $(\mathrm{N}=199)$ were University of Iowa students enrolled in an elementary psychology course. We invited participants with strong opinions for and against the legalization of abortion to participate. Participants were given a questionnaire which asked them to first identify their attitude towards legalized abortion $(-5=$ strongly opposed to,$+5=$ strongly in favor of). Participants were then presented with the 2 "pro-choice" value issues ( $A$ woman's right to determine her own reproductive course and Freedom from government interference in private lives), and the 2 "pro-life" issues (The value of human life and A moral code that demands responsibility for sexual conduct), with the order of the first and last two value issues counterbalanced across participants. For each issue, participants indicated their own position and estimated the position of the typical outgroup member on a single scale anchored by strongly opposed to (-5) and strongly in favor of (+5). To verify our intuitions that these values differentiated the core beliefs of each group, participants then rated $(1=$ not at all important, 11 
$=$ very important $)$ and rank-ordered $(1=$ most important, $4=$ least important $)$ each value issue in terms of its importance to their attitude stance.

Results

For all of the reported analyses, we averaged participants' ratings for the two pro-choice value issues and the two pro-life value issues. ${ }^{2}$

Value importance. Consistent with their self-proclaimed ideological positions, pro-choice participants rated and ranked the pro-choice value issues as more important to their attitude stance than the pro-life values, $t^{\prime} \mathrm{s}(124) \geq 3.63, p$ 's $<.001, d$ 's $\geq 0.32$. Pro-life participants, on the other hand, felt the pro-life values were more important than the pro-choice values, $t$ 's(73) > $8.75, p$ 's $\leq .001, d$ 's $\geq 1.02$. These differences in perceived value importance represent a necessary feature of our argument and are crucial to understanding the perceptions of disagreement reported below.

Actual disagreement. To be sure, there existed real differences of opinion between the groups. Relative to pro-life participants, pro-choicers had more favorable personal attitudes towards the pro-choice value issues $t(197)=11.52, p<.001, d=1.68$, and less favorable attitudes towards the pro-life issues, $t(197)=4.20, p<.001, d=0.61$ (see Tables 1 and 2 ). Thus, the two groups differed in their self-reported positions towards the value issues, in a manner congruent with their particular ideological preferences.

Perceived disagreement. To examine perceptions of disagreement, we compared participants' self-ratings and their estimates of the typical outgroup member. Larger scores indicate a greater absolute difference between the perceived opinions of self and outgroup. ${ }^{3} \mathrm{We}$ did this separately for the pro-choice and pro-life values, and submitted scores to a 2 (group: prochoice vs. pro-life) X 2 (value issue: pro-choice vs. pro-life) mixed-model ANOVA, with value 
issue as a within-subjects factor. As predicted, perceived disagreement was much greater concerning the important value issues than for the unimportant ones, as revealed by the highly significant Group X Value Issue interaction, $F(1,196)=186.32, p<.001, d=0.97$ (see Table 2). ${ }^{4}$

Looked at more closely, the pro-choice participants perceived more disagreement with their pro-life counterparts with respect to "women's reproductive rights" and "freedom from interference" than with respect to "the value of human life" and "a moral code," $t(123)=15.50, p$ $<.001, d=1.39$. The pro-life partisans saw matters much differently. For them, the true source of disagreement was with respect to the value of human life and a moral code, which they assumed they favored far more than pro-choicers did, while they perceived much less disagreement between themselves and pro-choicers regarding the two pro-choice value issues, $t(73)=5.74, p<.001, d=0.67$. There was also a significant main effect of value issue, $F(1,196)$ $=8.51, p<.01, d=0.21$, which revealed that perceptions of disagreement were generally greater about pro-choice values, and a non-significant main effect of group, $F<1, d=.06$.

Overestimated disagreement. Clearly, partisans perceived larger intergroup differences of opinion surrounding their own key values than about their adversaries' key values. Given the real differences of opinion already mentioned, to what extent were these imagined differences on (or off) of the mark? We compared participants' estimates of the outgroup opinion with the selfratings made by outgroup members as a benchmark. Lower (higher) numbers on this index indicate that partisans underestimated (overestimated) the extent to which their adversaries endorsed these admired values. In the 2 (group: pro-choice vs. pro-life) X 2 (value issue: prochoice vs. pro-life) ANOVA, there was the predicted Group X Value Issue interaction, $F(1,196)$ $=34.09, p<.001, d=0.41$, indicating that both partisan groups were more inaccurate when it 
came to estimating their adversaries' opinions for important issues rather than unimportant ones (see Table 2). Pro-choice participants underestimated the favorability of pro-lifers' opinions towards the pro-choice values by a greater margin than they did for the pro-life values, $t(123)=$ $3.80, p<.001, d=0.34$, while for pro-life participants, underestimation of the favorability of pro-choicers' opinions was more substantial for pro-life values than for pro-choice values, $t(73)$ $=4.55, p<.001, d=0.53$. There was also a significant main effect of group, $F(1,196)=9.78, p$ $<.01, d=0.22$, revealing that pro-life participants were more inaccurate overall in estimating pro-choicers' true opinions, and a non-significant value issue main effect, $F(1,196)=1.20, p>$ $.10, d=0.08$. Thus, not only did partisans assume their adversaries disagreed with them about the values underlying their own ideologies, these assumptions did not match the reality of their adversaries' true beliefs and so tended to be highly exaggerated.

Replication. As a partial replication of Study 1, we contacted numerous pro-choice advocacy groups around the Midwest and invited members of these groups to complete the same questionnaire anonymously (located on an internet website). Like their pro-choice student counterparts, these advocacy group members $(\mathrm{N}=361)$ felt the pro-choice issues were more important than the pro-life issues, $t$ 's(350) $\geq 8.80, p$ 's $\leq .001, d$ 's $\geq 0.47$. Most importantly, they perceived far more disagreement with pro-lifers about pro-choice issues than about pro-life issues, $t(348)=31.87, p<.001, d=1.70$ (see Table 3$)$. Interestingly, advocacy group members were even more extreme than our sample of college students were in how much disagreement they perceived about pro-choice issues, $t(473)=5.72, p<.001, d=0.59$. Advocacy group members and college students were more comparable in their perceptions about pro-life value issues, $t(473)=1.81, p=.04, d=0.19$. Two important points may be made about these findings. First, a reasonable assumption would be that advocacy group members might have a more 
balanced, nuanced view of their adversaries' opinions by virtue of their repeated exposure to prolifers' rhetoric and arguments. They did not. Second, these deeply committed advocacy group members were especially prone to perceive disagreement with their adversaries about personallyimportant issues. This suggests that attitude strength (or issue commitment) may moderate asymmetrical perceptions of disagreement.

\section{Study 2: Politics}

Our main goal in Study 2 was to extend these findings to a new domain of social conflict, namely the ongoing debate between Republicans and Democrats over national and international policy. Unlike with the partisan groups involved in the abortion debate, the agendas of these two groups are not mutually exclusive. Republican values seem to embrace a strong national defense and strict deterrence of crime, while Democrat values seem to embrace the elimination social inequalities and strengthening the public education system. Pre-testing conducted in our laboratory prior to this study confirmed that the groups did in fact view these values as being highly important to their political philosophies. While there is probably substantial overlap in the opinions of both groups regarding these values, our intuitions nevertheless told us that members of these partisans social groups would perceive (and overestimate) disagreement with their political adversaries, particularly for the values defining their own party doctrine.

A second broad goal of Study 2 was to examine the perceptions of individuals who were unaffiliated with either of the partisan groups. Our claim is that partisans assume disagreement with their adversaries along personally-relevant value issues rather than less relevant ones. This suggests that unaffiliated individuals (who do not subscribe to one set of values over another) would be less prone to the perceptions of disagreement that afflict partisans, and particularly, the highly exaggerated perceptions about personally-relevant values. To test this possibility, we 
included a group of politically-neutral participants and contrasted their responses with those of our Republican and Democrat samples.

\section{Method}

We pre-tested a large number of political issues to identify a set of four which differentiated the Republican and Democrat philosophies. Participants $(\mathrm{N}=88)$ in the main study were students recruited from an elementary psychology course at the University of Iowa. They were administered a questionnaire structured identically to the other studies, except they first indicated their political affiliation (Republican, Democrat, Neutral/Unaffiliated), and we substituted the abortion-related issues with the two value issues rated most important by Republicans (crime prevention and a strong military) and the two value issues rated most important by Democrats (funding of public education and eliminating social inequality) in pretesting.

Results

For all of the reported analyses, we averaged responses to the two conservative and two liberal value issues. ${ }^{5}$

Value importance. Not surprisingly, Republicans felt the two traditionally conservative value issues were more important to their political stance than the two traditionally liberal issues, $t$ 's $(27) \geq 1.88, \mathrm{p}$ 's $\leq .07, d$ 's $\geq 0.36$. In contrast, Democrats felt the liberal issues were more important than the conservative issues, $t^{\prime} \mathrm{s}(28) \geq 5.14, p$ 's $\leq .001, d$ 's $\geq 0.95$.

Actual disagreement. Republicans had more favorable personal attitudes towards the conservative value issues than the Democrats did, $t(55)=4.56, p<.001, d=1.21$, while Democrats had more favorable attitudes towards the liberal issues than the Republicans did, $t(55)$ $=6.23, p<.001, d=1.65($ see Tables 4 and 5). 
Perceived disagreement. Once again, partisans presumed more disagreement with their adversaries concerning personally-important value issues than for less important ones, as highlighted by the significant Group X Value Issue interaction, $F(1,55)=37.26, p<.001$, $d=0.81$ (see Table 5). More precisely, Republicans perceived greater disagreement with Democrats about the conservative values than about the liberal values, $t(27)=5.98, p<.001$, $d=1.13$, while Democrats perceived greater disagreement with Republicans about the liberal value issues than about the conservative ones, $t(28)=3.21, p<.01, d=0.60$. There was also a (trivial) main effect of group, $F(1,55)=6.14, p<.05, d=0.66$, indicating that Democrats perceived more overall disagreement than Republicans did, and a non-significant value issue main effect, $F<1, d=0.26$.

The politically-neutral participants, however, saw much less disagreement between Republicans and Democrats than these groups saw between themselves, at least in regards to the personally-important value issues. Concerning conservative value issues, Republicans saw more difference of opinion between themselves and Democrats than neutrals perceived between the two groups, $t(56)=3.41, p<.01, d=0.89$, while for liberal value issues, Democrats perceived more disagreement with Republicans than neutrals perceived between the groups, $t(57)=3.48, p$ $<.01, d=0.90$

Overestimated disagreement. Both Republicans and Democrats underestimated the favorability of each others' opinions for personally-important value issues by a greater margin than they did for the less important ones, as revealed by the significant Group X Value Issue interaction, $F(1,55)=26.93, p<.001, d=1.37$ (see Table 5). Among Democrats, underestimation of the Republican position was much greater for the liberal value issues than for the conservative issues $t(28)=6.15, p<.001, d=1.14$, while among Republicans, 
underestimation of the Democratic position was slightly greater for the conservative issues than for the liberal issues, but to a non-significant degree, $t<1, d=0.15$. There was also a significant value issue main effect, $F(1,55)=17.61, \mathrm{p}<.001, d=0.56$, showing that Republicans and Democrats were overall less accurate in estimating their adversaries' opinions about liberal value issues, and a non-significant main effect of group, $F<1, d=0.16$.

Here as well, the politically-neutral participants had a more balanced and accurate view of the partisans' true opinions than the partisans had about each other. In fact, Republicans underestimated the Democrat position towards the conservative values by a greater margin than the neutrals did, $t(56)=2.87, p<.01, d=0.77$, and Democrats underestimated the attitudes of Republicans towards the liberal value issues by a greater margin than the neutrals did, $t(57)=$ $1.83, p=.07, d=0.48$.

\section{General Discussion}

Researchers have established that member of partisan groups tend to have inaccurate perceptions regarding the attitudes and advocated positions of outgroup members (Robinson et al., 1995; Hovland et al., 1957). The present research examines the precise nature of these exaggerated perceptions. Our research suggests that partisans are most likely to perceive disagreement regarding those value issues they see as most central to their position.

The partisans in our studies were more alike in their opinions than they knew, and this fact was lost on them because, in their minds, the conflict was not about their adversaries' central values but their own. Ironically, this led to a situation where partisans disagreed about what they disagree about. Each side saw the other as irrationally and stubbornly challenging the very foundation of their personal ideologies, while seeing consensus of opinion about their adversaries' core values. Partisans seemed oblivious to the possibility that their adversaries 
shared many of their preferences and values, but differed primarily in how they prioritized those values. These misperceptions, in turn, may cultivate the very feelings of hostility and mistrust that lead to intergroup conflict in the first place.

We are left to speculate on the causes of these misperceptions. We believe a leading candidate explanation is cognitive egocentrism, or the tendency to give unwarranted attention to self-relevant information at the expense of information about other people (Chambers \& Windschitl, 2004; Kruger, 1999; Ross \& Sicoly, 1979). Applied to the present context, egocentrism suggests that partisans may think about their adversaries-- and the conflict more generally-- primarily from the vantage point of their own values. They may take their adversaries contrary position in the overall social debate as evidence that their adversaries oppose the values they see as the primary justification for their own position in this debate.

According to this egocentric view, partisans don't sufficiently consider the possibility that their adversaries define the debate according to a different set of ideological values. From this perspective, one reason those on the pro-choice side see their opponents as combative, illogical, and dogmatic is because, in the pro-choice mindset, pro-life advocates desire to undermine what they believe is as most at stake in the abortion debate-women's right to selfdetermination (for similar findings concerning union-management negotiations, see Robinson \& Friedman, 1995). They have difficulty appreciating that pro-lifers oppose legalized abortion because of a deep devotion to a competing value, namely, the reverence for human life (for research demonstrating the role of egocentrism in other intergroup situations, see Thompson \& Loewenstein, 1992; Wade-Benzoni, Tenbrunsel, \& Bazerman, 1996; and in perspective-taking more generally, see Epley, Keysar, Van Boven, \& Gilovich, 2004; Nickerson, 1999; Ross, Greene, \& House, 1977; Hass, 1986). 
An explanation based upon self or ingroup-enhancement motivations seems less tenable for several reasons. For one, partisans acknowledged their adversaries' favorable attitudes towards personally-unimportant but admirable value issues, even admitting that they themselves had less favorable positions towards those issues. Partisans judged their adversaries to have more admirable positions even though their absolute importance ratings for those values implied that they were perceived as moderately relevant to their personal attitudes. A purely motivational account (one based upon ingroup favoritism and outgroup derogation) might suggest that partisans would perceive their adversaries' as less admirable on all value issues, which the partisans in our studies clearly did not do. General group stereotypes also seem less plausible as an explanation for our findings. If general stereotypes were operating, we would expect to see some uniformity in the estimates offered by different groups about their own and their adversaries' opinions (e.g., a stereotype that Democrats disfavor a strong military would imply that Republican, Democrat, and politically-neutral persons alike would share this belief).

Do our findings suggest any practical solutions for reducing intergroup conflict, and perhaps, conflict in other types of social bonds? The first and perhaps most obvious solution is informing partisans about the actual basis for their adversaries' opinions, specifically challenging their misconceptions about their adversaries' opinions about personally-relevant values (for research gauging the effectiveness of this solution, see Keltner \& Robinson, 1993; Thompson \& Hastie, 1990). A second and more subtle approach, one that has yet to be empirically tested, would be to have partisans think about the social conflict through the frame of their adversaries' ideological values. Doing so might bring partisans to the realization that, not only is there an alternative and equally-valid set of ideals involved in the debate, there is shared opinion between self and adversaries about those ideals. Indeed, the recognition one's adversaries hold a more 
favorable opinion about those values than does oneself (as occurred in the present studies) may be a powerful antidote against feelings of enmity and mistrust. 


\section{Author Notes}

John R. Chambers, Department of Psychology, University of Iowa (after August 2005, at the Department of Psychology, University of Florida). Robert S. Baron, Department of Psychology, University of Iowa. Mary L. Inman, Department of Psychology, Hope College.

We are grateful to Paul Windschitl for his comments on an earlier draft of this paper.

This research was aided by a University of Iowa Dissertation Fellowship to the first author.

Correspondence concerning this article should be addressed to John R. Chambers, Department of Psychology, University of Iowa, Iowa City, IA 52242. E-mail: johnchambers@uiowa.edu 


\section{Footnotes}

${ }^{1}$ In each study, we also collected estimates of the ingroup opinion. These estimates were highly similar to self-ratings in all cases. Therefore, our findings and conclusions about perceived disagreement also extend to situations where partisans think about general differences of opinion between ingroup and outgroup members.

${ }^{2}$ Analyses of the individual items (comparing responses to the various important and unimportant value issues) yielded similar results.

${ }^{3}$ We were interested only in the absolute magnitude of perceived differences of opinion. Nevertheless, all of the reported differences in perceived disagreement remain significant when the direction of estimated opinion was taken into account.

${ }^{4}$ Partisans also tended to exaggerate the actual amount of disagreement with their adversaries concerning personally important value issues. For example, pro-choice participants in Study 1 had more favorable attitudes towards the pro-choice issues than the pro-lifers had, but their perceptions about this difference were highly inflated.

${ }^{5}$ Degrees of freedom vary slightly due to missing responses. 


\section{References}

Chambers, J. R., \& Windschitl, P. D. (2004). Biases in social comparative judgments: The role of non-motivated factors in above-average and comparative-optimism effects.

Psychological Bulletin, 130, 813-838.

Epley, N., Keysar, B., Van Boven, L., \& Gilovich, T. (2004). Perspective taking as egocentric anchoring and adjustment. Journal of Personality \& Social Psychology, 87, 327-339.

Hass, R. G. (1984). Perspective taking and self-awareness: Drawing an E on your forehead. Journal of Personality \& Social Psychology, 46, 788-798.

Hovland, C. I., Harvey, O. J., \& Sherif, M. (1957). Assimilation and contrast effects in reactions to communication and attitude change. Journal of Abnormal \& Social Psychology, 55, 244-252.

Keltner, D., \& Robinson, R. J. (1993). Imagined ideological differences in conflict escalation and resolution. International Journal of Conflict Management, 4, 249-262.

Keltner, D., \& Robinson, R. J. (1997). Defending the status quo: Power and bias in social conflict. Personality \& Social Psychology Bulletin, 23, 1066-1077.

Keltner, D., \& Robinson, R. J. (1996). Extremism, power, and the imagined basis of social conflict. Current Directions in Psychological Science, 5, 101-105.

Kruger, J. (1999). Lake Wobegon be gone! The "below-average effect" and the egocentric nature of comparative ability judgments. Journal of Personality \& Social Psychology, 77, 221232.

Nickerson, R. S. (1999). How we know--and sometimes misjudge--what others know: Imputing one's own knowledge to others. Psychological Bulletin, 125, 737-759.

Robinson, R. J., \& Keltner, D. (1996). Much ado about nothing? Revisionists and traditionalists choose an introductory English syllabus. Psychological Science, 7, 18-24.

Robinson, R. J., Keltner, D., Ward, A., \& Ross, L. (1995). Actual versus assumed differences in construal: "Naive realism" in intergroup perception and conflict. Journal of Personality \& Social Psychology, 68, 404-417.

Robinson, R. J., \& Friedman, R. A. (1995). Mistrust and misconstrual in union-management relationships: Causal accounts in adversarial contexts. International Journal of Conflict Management, 6, 312-327. 
Ross, L., Greene, D., \& House, P. (1977). The false consensus effect: An egocentric bias in social perception and attribution processes. Journal of Experimental Social Psychology, 13, 279-301.

Thompson, L., \& Nadler, J. (2000). Judgmental biases in conflict resolution and how to overcome them. In M. Deutsch \& P. T. Coleman (Eds.). The handbook of conflict resolution: Theory and practice. (pp. 213-235).

Thompson, L. (1995). "They saw a negotiation": Partisanship and involvement. Journal of Personality \& Social Psychology, 68, 839-853.

Thompson, L., \& Hastie, R. (1990). Social perception in negotiation. Organizational Behavior \& Human Decision Processes, 47, 98-123.

Thompson, L., \& Loewenstein, G. (1992). Egocentric interpretations of fairness and interpersonal conflict. Organizational Behavior \& Human Decision Processes, 51, 176197.

Wade-Benzoni, K. A., Tenbrunsel, A. E., \& Bazerman, M. H. (1996). Egocentric interpretations of fairness in asymmetric, environmental social dilemmas: Explaining harvesting behavior and the role of communication. Organizational Behavior \& Human Decision Processes, 67, 111-126. 
Table 1

Average self-ratings and outgroup estimates among pro-choice and pro-life participants in Study 1

\begin{tabular}{|c|c|c|c|c|}
\hline \multirow[b]{3}{*}{ Value issue } & \multicolumn{2}{|c|}{$\begin{array}{c}\text { Self } \\
\text { ratings }\end{array}$} & \multicolumn{2}{|c|}{$\begin{array}{l}\text { Outgroup } \\
\text { estimates }\end{array}$} \\
\hline & $\begin{array}{c}\text { PCs } \\
(\mathrm{n}=125)\end{array}$ & $\begin{array}{c}\text { PLs } \\
(\mathrm{n}=74)\end{array}$ & $\begin{array}{c}\text { PCs } \\
\text { of PLs }\end{array}$ & $\begin{array}{l}\text { PLs } \\
\text { of PCs }\end{array}$ \\
\hline & $\begin{array}{c}M \\
(S D)\end{array}$ & $\begin{array}{c}M \\
(S D)\end{array}$ & $\begin{array}{c}M \\
(S D)\end{array}$ & $\begin{array}{c}M \\
(S D)\end{array}$ \\
\hline Reproductive rights & $\begin{array}{c}4.09 \\
(1.28)\end{array}$ & $\begin{array}{l}-0.04 \\
(3.09)\end{array}$ & $\begin{array}{l}-1.85 \\
(2.65)\end{array}$ & $\begin{array}{c}2.64 \\
(2.84)\end{array}$ \\
\hline Freedom from interference & $\begin{array}{c}3.15 \\
(1.78)\end{array}$ & $\begin{array}{c}1.61 \\
(2.24)\end{array}$ & $\begin{array}{l}-\mathbf{- 0 . 5 3} \\
(\mathbf{2 . 8 8})\end{array}$ & $\begin{array}{c}1.86 \\
(3.29)\end{array}$ \\
\hline Average pro-choice values & $\begin{array}{c}3.62 \\
(1.32)\end{array}$ & $\begin{array}{c}0.78 \\
(2.16)\end{array}$ & $\begin{array}{l}-1.19 \\
(2.35)\end{array}$ & $\begin{array}{c}2.25 \\
(2.58)\end{array}$ \\
\hline Value of human life & $\begin{array}{c}3.90 \\
(1.34)\end{array}$ & $\begin{array}{c}4.58 \\
(0.70)\end{array}$ & $\begin{array}{c}3.13 \\
(2.84)\end{array}$ & $\begin{array}{c}0.92 \\
(2.84)\end{array}$ \\
\hline Moral code of sexual conduct & $\begin{array}{c}1.81 \\
(2.75)\end{array}$ & $\begin{array}{c}2.99 \\
(1.90)\end{array}$ & $\begin{array}{c}2.82 \\
(2.81)\end{array}$ & $\begin{array}{l}-1.38 \\
(2.53)\end{array}$ \\
\hline Average pro-life values & $\begin{array}{c}2.85 \\
(1.70)\end{array}$ & $\begin{array}{c}3.78 \\
(1.11)\end{array}$ & $\begin{array}{c}2.97 \\
(2.63)\end{array}$ & $\begin{array}{l}-0.23 \\
(2.21)\end{array}$ \\
\hline
\end{tabular}

Note: $\mathrm{PC}=$ Pro-choice, $\mathrm{PL}=$ Pro-life. Self-ratings and outgroup estimates were made on a -5 (strong opposed to) to +5 (strongly in favor of) scale. Numbers in bold represent important value issues for the group in question, whereas those in italics represent less important value issues. 
Table 2

Average actual, perceived, and overestimated disagreement among pro-choice and pro-life participants in Study 1

\begin{tabular}{|c|c|c|c|c|c|}
\hline \multirow[b]{3}{*}{ Value issue } & \multirow{3}{*}{$\begin{array}{c}\begin{array}{c}\text { Actual } \\
\text { disagreement }\end{array} \\
M \\
(S E) \\
\end{array}$} & \multicolumn{2}{|c|}{$\begin{array}{c}\text { Perceived } \\
\text { disagreement }\end{array}$} & \multicolumn{2}{|c|}{$\begin{array}{c}\text { Overestimated } \\
\text { disagreement }\end{array}$} \\
\hline & & $\begin{array}{l}\text { Among } \\
\text { PCs }\end{array}$ & $\begin{array}{l}\text { Among } \\
\text { PLs }\end{array}$ & $\begin{array}{l}\text { PCs } \\
\text { of PLs }\end{array}$ & $\begin{array}{l}\text { PLs } \\
\text { of PCs }\end{array}$ \\
\hline & & $\begin{array}{c}M \\
(S D) \\
\end{array}$ & $\begin{array}{c}M \\
(S D) \\
\end{array}$ & $\begin{array}{c}M \\
(S D)\end{array}$ & $\begin{array}{c}M \\
(S D)\end{array}$ \\
\hline Reproductive rights & $\begin{array}{c}4.13 \\
(0.31)\end{array}$ & $\begin{array}{c}5.94 \\
(\mathbf{3 . 0 5})\end{array}$ & $\begin{array}{c}2.68 \\
(4.75)\end{array}$ & $\begin{array}{l}-1.81 \\
(2.65)\end{array}$ & $\begin{array}{l}-1.45 \\
(2.83)\end{array}$ \\
\hline Freedom from interference & $\begin{array}{c}1.54 \\
(0.29)\end{array}$ & $\begin{array}{c}3.68 \\
(\mathbf{3 . 3 3})\end{array}$ & $\begin{array}{c}0.26 \\
(3.89)\end{array}$ & $\begin{array}{l}-2.14 \\
(2.88)\end{array}$ & $\begin{array}{l}-1.29 \\
(3.29)\end{array}$ \\
\hline Average pro-choice values & $\begin{array}{c}2.84 \\
(0.25)\end{array}$ & $\begin{array}{c}4.81 \\
(2.73)\end{array}$ & $\begin{array}{c}1.47 \\
(3.41)\end{array}$ & $\begin{array}{l}-1.97 \\
(2.35)\end{array}$ & $\begin{array}{l}-1.37 \\
(2.58)\end{array}$ \\
\hline Value of human life & $\begin{array}{c}0.69 \\
(0.17)\end{array}$ & $\begin{array}{c}0.77 \\
(3.12)\end{array}$ & $\begin{array}{c}3.66 \\
(2.84)\end{array}$ & $\begin{array}{l}-1.45 \\
(2.84)\end{array}$ & $\begin{array}{l}-2.98 \\
(2.84)\end{array}$ \\
\hline Moral code of sexual conduct & $\begin{array}{c}1.18 \\
(0.36)\end{array}$ & $\begin{array}{c}1.00 \\
(4.36)\end{array}$ & $\begin{array}{c}4.36 \\
(3.28)\end{array}$ & $\begin{array}{l}-0.17 \\
(2.81)\end{array}$ & $\begin{array}{l}-3.19 \\
(2.53)\end{array}$ \\
\hline Average pro-life values & $\begin{array}{c}0.93 \\
(0.22)\end{array}$ & $\begin{array}{c}0.90 \\
(1.75)\end{array}$ & $\begin{array}{c}4.01 \\
(2.55)\end{array}$ & $\begin{array}{l}-0.82 \\
(2.63)\end{array}$ & $\begin{array}{l}-3.08 \\
(2.21)\end{array}$ \\
\hline
\end{tabular}

Note: PC = Pro-choice, PL = Pro-life. Actual disagreement computed from the absolute difference between PL's self-ratings and PC's self-ratings. Perceived disagreement was computed from the absolute difference between self-ratings and outgroup estimates. Overestimated disagreement was computed by subtracting the outgroup's self-ratings from outgroup estimates. Numbers in bold represent important value issues for the group in question, whereas those in italics represent less important value issues. 
Table 3

Average self-ratings, outgroup estimates, and perceived disagreement among pro-choice advocacy group members in replication

\begin{tabular}{|c|c|c|c|}
\hline & $\begin{array}{c}\text { Self } \\
\text { ratings }\end{array}$ & $\begin{array}{l}\text { Outgroup } \\
\text { estimates }\end{array}$ & $\begin{array}{c}\text { Perceived } \\
\text { disagreement }\end{array}$ \\
\hline & $\begin{array}{c}\text { PCs } \\
(\mathrm{n}=361)\end{array}$ & $\begin{array}{c}\text { PCs } \\
\text { of PLs }\end{array}$ & $\begin{array}{l}\text { Among } \\
\text { PC's }\end{array}$ \\
\hline Value issue & $\begin{array}{c}M \\
(S D) \\
\end{array}$ & $\begin{array}{c}M \\
(S D) \\
\end{array}$ & $\begin{array}{c}M \\
(S D) \\
\end{array}$ \\
\hline Reproductive rights & $\begin{array}{c}4.87 \\
(0.45)\end{array}$ & $\begin{array}{l}-3.37 \\
(2.12)\end{array}$ & $\begin{array}{c}8.24 \\
(2.16)\end{array}$ \\
\hline Freedom from interference & $\begin{array}{c}3.84 \\
(1.31)\end{array}$ & $\begin{array}{c}\mathbf{- 0 . 4 8} \\
(3.17)\end{array}$ & $\begin{array}{c}4.32 \\
(3.68)\end{array}$ \\
\hline Average pro-choice values & $\begin{array}{c}4.36 \\
(0.73)\end{array}$ & $\begin{array}{l}-1.93 \\
(2.12)\end{array}$ & $\begin{array}{c}6.28 \\
(2.38)\end{array}$ \\
\hline Value of human life & $\begin{array}{c}4.59 \\
(0.96)\end{array}$ & $\begin{array}{c}3.71 \\
(2.61)\end{array}$ & $\begin{array}{c}0.88 \\
(2.62)\end{array}$ \\
\hline Moral code of sexual conduct & $\begin{array}{c}2.37 \\
(2.98)\end{array}$ & $\begin{array}{c}4.05 \\
(1.96)\end{array}$ & $\begin{array}{l}1.68 \\
(3.46)\end{array}$ \\
\hline Average pro-life values & $\begin{array}{c}3.48 \\
(1.57)\end{array}$ & $\begin{array}{c}3.87 \\
(1.87)\end{array}$ & $\begin{array}{l}1.28 \\
(2.11)\end{array}$ \\
\hline
\end{tabular}

Note: $\mathrm{PC}=$ Pro-choice, $\mathrm{PL}=$ Pro-life. Self-ratings and outgroup estimates were made on a -5 (strong opposed to) to +5 (strongly in favor of) scale. Perceived disagreement was computed from the absolute difference between self-ratings and outgroup estimates.

Numbers in bold represent important value issues for the group in question, whereas those in italics represent less important value issues. 
Table 4

Average self-ratings and outgroup estimates among Republican, Democrat, and Neutral participants in Study 2

\begin{tabular}{|c|c|c|c|c|c|c|}
\hline \multirow[b]{3}{*}{ Value issue } & \multicolumn{2}{|c|}{$\begin{array}{c}\text { Self } \\
\text { ratings }\end{array}$} & \multicolumn{4}{|c|}{$\begin{array}{l}\text { Outgroup } \\
\text { estimates }\end{array}$} \\
\hline & $\begin{array}{c}\text { REPs } \\
(\mathrm{n}=28)\end{array}$ & $\begin{array}{c}\text { DEMs } \\
(\mathrm{n}=29)\end{array}$ & $\begin{array}{l}\text { REPs } \\
\text { of DEMs }\end{array}$ & $\begin{array}{c}\text { DEMs } \\
\text { of REPs }\end{array}$ & $\begin{array}{l}\text { NEUTs } \\
\text { of REPs }\end{array}$ & $\begin{array}{l}\text { NEUTs } \\
\text { of DEMs }\end{array}$ \\
\hline & $\begin{array}{c}M \\
(S D)\end{array}$ & $\begin{array}{c}M \\
(S D)\end{array}$ & $\begin{array}{c}M \\
(S D)\end{array}$ & $\begin{array}{c}M \\
(S D)\end{array}$ & $\begin{array}{c}M \\
(S D)\end{array}$ & $\begin{array}{c}M \\
(S D)\end{array}$ \\
\hline Public education & $\begin{array}{c}3.75 \\
(1.18)\end{array}$ & $\begin{array}{c}4.52 \\
(1.09)\end{array}$ & $\begin{array}{c}3.43 \\
(1.32)\end{array}$ & $\begin{array}{c}1.07 \\
(2.58)\end{array}$ & $\begin{array}{c}1.97 \\
(2.37)\end{array}$ & $\begin{array}{c}3.00 \\
(1.62)\end{array}$ \\
\hline Eliminating poverty & $\begin{array}{c}2.04 \\
(1.69)\end{array}$ & $\begin{array}{c}4.31 \\
(0.89)\end{array}$ & $\begin{array}{c}3.89 \\
(1.34)\end{array}$ & $\begin{array}{c}\mathbf{- 0 . 3 4} \\
(2.54)\end{array}$ & $\begin{array}{c}0.80 \\
(2.11)\end{array}$ & $\begin{array}{c}3.00 \\
(2.23)\end{array}$ \\
\hline Average Democrat values & $\begin{array}{c}2.89 \\
(1.09)\end{array}$ & $\begin{array}{c}4.41 \\
(0.72)\end{array}$ & $\begin{array}{c}3.66 \\
(1.12)\end{array}$ & $\begin{array}{c}0.36 \\
(2.31)\end{array}$ & $\begin{array}{c}1.38 \\
(1.97)\end{array}$ & $\begin{array}{c}3.00 \\
(1.76)\end{array}$ \\
\hline Crime prevention & $\begin{array}{c}3.57 \\
(1.26)\end{array}$ & $\begin{array}{c}1.79 \\
(2.62)\end{array}$ & $\begin{array}{c}0.85 \\
(2.23)\end{array}$ & $\begin{array}{c}3.76 \\
(1.35)\end{array}$ & $\begin{array}{c}2.97 \\
(2.67)\end{array}$ & $\begin{array}{c}1.33 \\
(2.28)\end{array}$ \\
\hline Strong military & $\begin{array}{c}3.79 \\
(1.20)\end{array}$ & $\begin{array}{c}1.21 \\
(2.41\end{array}$ & $\begin{array}{c}0.04 \\
(2.08)\end{array}$ & $\begin{array}{c}4.24 \\
(0.83)\end{array}$ & $\begin{array}{c}3.23 \\
(2.32)\end{array}$ & $\begin{array}{c}2.13 \\
(1.80)\end{array}$ \\
\hline Average Republican values & $\begin{array}{c}3.68 \\
(1.00)\end{array}$ & $\begin{array}{c}1.50 \\
(2.33)\end{array}$ & $\begin{array}{c}0.44 \\
(1.88)\end{array}$ & $\begin{array}{c}4.00 \\
(1.04)\end{array}$ & $\begin{array}{c}3.10 \\
(1.88)\end{array}$ & $\begin{array}{c}1.73 \\
(1.52)\end{array}$ \\
\hline
\end{tabular}

Note: REP = Republican, DEM = Democrat, NEUT = Neutral. Self-ratings and outgroup estimates were made on a -5 (strong opposed to) to +5 (strongly in favor of) scale. Numbers in bold represent important value issues for the group in question, whereas those in italics represent less important value issues. 
Table 5

Average actual, perceived, and overestimated disagreement among Republican, Democrat, and Neutral participants in Study 2

\begin{tabular}{|c|c|c|c|c|c|c|c|c|}
\hline \multirow[b]{3}{*}{ Value issue } & \multirow{3}{*}{$\begin{array}{c}\begin{array}{c}\text { Actual } \\
\text { disagreement }\end{array} \\
M \\
(S E)\end{array}$} & \multicolumn{3}{|c|}{$\begin{array}{c}\text { Perceived } \\
\text { disagreement }\end{array}$} & \multicolumn{4}{|c|}{$\begin{array}{l}\text { Overestimated } \\
\text { disagreement }\end{array}$} \\
\hline & & $\begin{array}{l}\text { Among } \\
\text { REPs }\end{array}$ & $\begin{array}{l}\text { Among } \\
\text { DEMs }\end{array}$ & $\begin{array}{l}\text { Among } \\
\text { NEUTs }\end{array}$ & $\begin{array}{c}\text { REPs } \\
\text { of DEMs }\end{array}$ & $\begin{array}{c}\text { DEMs } \\
\text { of REPs }\end{array}$ & $\begin{array}{l}\text { NEUTs } \\
\text { of DEMs }\end{array}$ & $\begin{array}{l}\text { NEUTs } \\
\text { of REPs }\end{array}$ \\
\hline & & $\begin{array}{c}M \\
(S D)\end{array}$ & $\begin{array}{c}M \\
(S D)\end{array}$ & $\begin{array}{c}M \\
(S D)\end{array}$ & $\begin{array}{c}M \\
(S D)\end{array}$ & $\begin{array}{c}M \\
(S D)\end{array}$ & $\begin{array}{c}M \\
(S D)\end{array}$ & $\begin{array}{c}M \\
(S D)\end{array}$ \\
\hline Public education & $\begin{array}{c}0.77 \\
(0.30)\end{array}$ & $\begin{array}{c}0.32 \\
(1.66)\end{array}$ & $\begin{array}{c}3.45 \\
(2.53)\end{array}$ & $\begin{array}{c}1.03 \\
(3.03)\end{array}$ & $\begin{array}{l}-1.09 \\
(1.32)\end{array}$ & $\begin{array}{l}-2.68 \\
(2.58)\end{array}$ & $\begin{array}{l}-1.52 \\
(1.62)\end{array}$ & $\begin{array}{l}-1.78 \\
(2.37)\end{array}$ \\
\hline Eliminating poverty & $\begin{array}{c}2.28 \\
(0.36)\end{array}$ & $\begin{array}{l}1.86 \\
(1.96)\end{array}$ & $\begin{array}{l}4.66 \\
(2.65)\end{array}$ & $\begin{array}{c}2.20 \\
(3.53)\end{array}$ & $\begin{array}{l}-0.42 \\
(1.34)\end{array}$ & $\begin{array}{l}-2.38 \\
(2.54)\end{array}$ & $\begin{array}{l}-1.31 \\
(2.23)\end{array}$ & $\begin{array}{l}-1.24 \\
(2.11)\end{array}$ \\
\hline Average Democrat values & $\begin{array}{c}1.52 \\
(0.24)\end{array}$ & $\begin{array}{l}1.09 \\
(1.26)\end{array}$ & $\begin{array}{l}4.05 \\
(2.35)\end{array}$ & $\begin{array}{l}1.62 \\
(2.97)\end{array}$ & $\begin{array}{l}-0.75 \\
(1.12)\end{array}$ & $\begin{array}{l}-2.53 \\
(2.31)\end{array}$ & $\begin{array}{l}-1.42 \\
(1.76)\end{array}$ & $\begin{array}{l}-1.51 \\
(1.97)\end{array}$ \\
\hline Crime prevention & $\begin{array}{c}1.78 \\
(0.55)\end{array}$ & $\begin{array}{c}2.72 \\
(1.96)\end{array}$ & $\begin{array}{c}1.97 \\
(3.11)\end{array}$ & $\begin{array}{c}1.63 \\
(3.70)\end{array}$ & $\begin{array}{l}-0.94 \\
(2.19)\end{array}$ & $\begin{array}{c}0.19 \\
(1.35)\end{array}$ & $\begin{array}{l}-0.46 \\
(2.28)\end{array}$ & $\begin{array}{l}-0.60 \\
(2.27)\end{array}$ \\
\hline Strong military & $\begin{array}{c}2.58 \\
(0.51)\end{array}$ & $\begin{array}{c}3.75 \\
(2.19)\end{array}$ & $\begin{array}{c}3.03 \\
(2.65)\end{array}$ & $\begin{array}{c}1.10 \\
(3.19)\end{array}$ & $\begin{array}{l}-1.17 \\
(2.08)\end{array}$ & $\begin{array}{c}0.45 \\
(0.83)\end{array}$ & $\begin{array}{c}0.92 \\
(1.80)\end{array}$ & $\begin{array}{l}-0.56 \\
(2.31)\end{array}$ \\
\hline Average Republican values & $\begin{array}{c}2.18 \\
(0.48)\end{array}$ & $\begin{array}{c}3.23 \\
(1.53)\end{array}$ & $\begin{array}{c}2.50 \\
(2.67)\end{array}$ & $\begin{array}{c}1.37 \\
(2.49)\end{array}$ & $\begin{array}{l}-1.06 \\
(1.89)\end{array}$ & $\begin{array}{c}0.32 \\
(1.04)\end{array}$ & $\begin{array}{c}0.23 \\
(1.52)\end{array}$ & $\begin{array}{l}-0.58 \\
(1.88)\end{array}$ \\
\hline
\end{tabular}

Note: REP = Republican, DEM = Democrat, NEUT = Neutral. Actual disagreement was computed from the absolute difference between REP's self-ratings and DEM's self-ratings. Perceived disagreement was computed from the absolute difference between selfratings and outgroup estimates (among NEUT, perceived disagreement was the absolute difference between outgroup estimates about REPs and DEMs). Overestimated disagreement was computed by subtracting the outgroup's self-ratings from outgroup estimates. Numbers in bold represent important value issues for the group in question, whereas those in italics represent less important value issues. 
